\title{
A Study of College English Blended Learning Model Based on the Blue Ink Cloud Class*
}

\author{
Lu Yan \\ School of Foreign Languages \\ Jilin Business and Technology College \\ Jilin, China 130000
}

\begin{abstract}
With the development of information technology and the popularization of the Internet, experts and scholars in the educational field have made a series of explorations and practices on E-learning. The idea of blended learning has gradually been recognized and applied to teaching practice. Blended learning is based on certain teaching and learning objectives, combining the advantages of traditional learning methods with those of online learning by using appropriate technical means. Teachers should play a leading role in guiding, inspiring and supervising the teaching process, during which, as the main body of the learning process, students' initiative, and creativity are fully reflected. The paper mainly discusses the application of mobile Blue Ink Cloud Class in college English teaching is just adapted to this trend. Choosing Blue Ink Cloud Class as an assistant teaching terrace for blended learning in mobile environment has great advantages and feasibility. The study has a very new significance of the times and will provide a new perspective for the reform of College English teaching from multiple angles and levels in the era of "Internet plus".
\end{abstract}

Keywords-blended learning; blue ink cloud class; college English

\section{INTRODUCTION}

With the wide acceptance of blended learning, it has attracted a large number of experts and scholars to carry out the practical teaching. Blended learning should be carried out with the help of a certain network platform. Practice has proved that many network teaching platforms have defects, it can't fully complete the combination of online and offline classroom teaching. After screening and comparing, although some functions of Blue Ink Cloud Class need to be improved, the researchers found that the platform of Blue ink cloud class is more suitable for blended learning. Blue ink cloud class Platform provides convenience for students to carry out online learning. Teachers and students can interact through this platform.

The study aims to construct the blended teaching model of College English based on Blue Ink Cloud Class by investigating the motivation of non-English majors in foreign language learning through questionnaires. The paper puts forward a new scheme of College English teaching reform

*Fund: The 13th five-year plan for education and science of Jilin province (ZD18103) through the application of blended teaching based on Blue ink cloud classes in College English courses. On this basis, this paper explores the impact of the teaching model on the motivation and learning effect of non-English majors.

\section{Construction of Practice Teaching Model}

The paper explores the influence of the teaching model on the motivation and learning effect of non-English majors' English learning. The use of Blue Ink Cloud Class in College English class has changed the way of evaluating and assessing the final scores in the past. The use of Blue Ink Cloud Class in College English class has changed the traditional way of evaluating and assessing final grades.

The whole teaching process is divided into three parts, namely, the students' autonomous learning before class, the knowledge internalization in class and the consolidation and expansion of knowledge after class.

\section{A. The Pre-class Stage}

In the pre-class stage, teachers publish preview notices and upload related resources on the platform of Blue Ink Cloud Class. After receiving the message reminder from the platform, students can enter the class to view and download learning resources. In order to ensure that each students prepares for the class before lessons and conduct autonomous learning efficiently, the pre-class preparation requires students to learn related knowledge independently. Teacher should design and arrange this link carefully. The preview assignment mainly includes the following aspects, taking Unit four as an example. First, teachers should collate and summarize the use of key words and phrases in this unit, upload them to Blue Ink Cloud resources and upload vocabulary exercises in "Brain storming". Second, during the question-answering discussion, teachers should focus on this topic "The test of love" ask students to answer the following questions, such as:

(A) Choose one of the statements in the following and discuss it with your partners. What's your understanding of it?

Love is blind. /Love can neither be bought nor sold. / Love me, love my dog. Beauty lies in the eyes of the beholder. 
suggestions. Teachers can carry out teaching according to students' feedback, adjusting teaching plans appropriately, and prepare for the implementation of the next classroom task. This process also fully reflects the essence of "teaching by learning". In a word, the teaching mode of College English reading and writing course based on Blue Ink Cloud Class meets the needs of the times and is a favorable platform for promoting college English teaching in the knowledge era.

\section{RESEARCH METHODOLGY}

After more than three semesters of classroom practice, 58 students in the experimental class of Grade 2017 were surveyed with questionnaires. The survey results show that most of the students still approve of the combination of Blue Ink Cloud Classes, and are willing to choose the way of College English teaching based on Blue ink classes. 76.75\% of the students liked the blue ink class very much. In the main activities of the class, "roll call" and "classroom test" are the most popular, accounting for $33.33 \%$ and $33.89 \%$ of the total respectively. In order to compare the learning effect of students before and after the experiment, the author used standardized test papers for pre-test and post-test, and sample T-test in the experimental class and the control class independently.

\section{A. Students' Learning Motivation Has Been Improved}

After one semester's study, through a questionnaire survey on learning motivation, the results show that both the control group and the experimental group have improved their learning motivation, but the students who take part in the Blue Ink Cloud Classes are generally showed stronger motivation for learning than those in the regular college English teaching class in the final examination. In the experimental class, students' English learning motivation has been greatly improved compared with that before the experiment. Based on the interviews with students and the situation of classroom observation, the reason for the analysis is the innovation of teaching methods, which stimulates the students' enthusiasm for independent learning.

The Blue Ink Cloud Class adds consideration to the professional background and interests of the students, adopts mixed teaching, and step-by-step approach. The teachers take into account the consolidation of basic English and focus on improving students' interest in teaching students as a means of teaching and training students' oral communication skills, helping students improve the practical application of English.

We can draw a preliminary conclusion that the Blue ink class teaching mode in College English teaching can effectively improve the learning motivation of Chinese English learners and conform to the applied talents training model. 


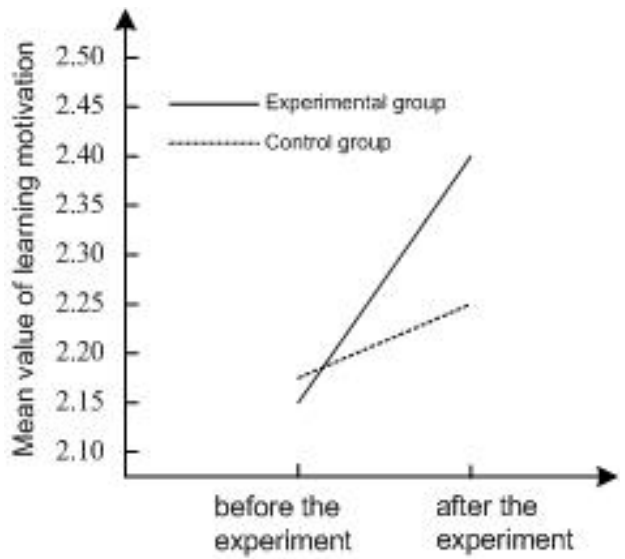

Fig. 1. Comparison of learning motivation before and after the experiment.

\section{B. The Overall English Proficiency of the Students Has Been Significantly Improved}

After the pre-test and post-test of the experiment were finished, the authors separately calculated the test scores of the two classes and calculated their average scores. After the experiment, the test results of the students' overall English level are as follows: the foreign language teaching mode of blue ink cloud class and the regular college English teaching mode all contribute to the improvement of the English level of the students.

However, compared with the regular college English class, students in the foreign language teaching class with more information means can improve their overall English level more quickly $(\mathrm{t}=5.23, \mathrm{p}<0.05)$, showing a higher language acquisition skills, which are embodied in reading $(\mathrm{t}$ $=2.57, \mathrm{P}<0.05)$ and listening improvement $(\mathrm{t}=5.89, \mathrm{P}<$ $0.05)$.

Through a series of qualitative studies, the research team also found that after one semester of study, compared with the control group students, the students in the experimental group used language skills and speaking skills in specific contexts were significantly improved than the beginning of the experiment. The blue ink cloud class foreign language teaching has increased the opportunities for cultivating students' comprehensive use of language.

TABLE I. COMPARISON OF COMPREHENSIVE ENGLISH WATER ASSESSMENT TEST AFTER THE EXPERIMENT OF COLLEGE ENGLISH BLUE INK Cloud ClASS TEACHING MODEL

\begin{tabular}{|c|c|c|c|c|c|c|}
\hline \multirow[t]{2}{*}{ Variables } & \multicolumn{2}{|c|}{ Experimental group $(n=58)$} & \multicolumn{4}{|c|}{ Control group $(n=56)$} \\
\hline & Mean value & $\begin{array}{l}\text { Standard } \\
\text { deviation }\end{array}$ & Mean value & Standard deviation & $T$ & $\boldsymbol{P}$ \\
\hline Listening & 25.31 & 2.67 & 21.23 & 2.58 & 5.89 & 0.05 \\
\hline Reading & 26.78 & 2.05 & 20.56 & 1.67 & 2.57 & 0.06 \\
\hline Translation & 7.81 & 0.17 & 9.45 & 1.08 & 1.24 & 0.26 \\
\hline Writing & 9.23 & 0.34 & 9.65 & 1.57 & -0.87 & 0.41 \\
\hline Total & 69.13 & 5.23 & 60.89 & 6.90 & 4.13 & 0.00 \\
\hline
\end{tabular}

The average scores of the pre-test scores of the experimental class and the control class are: 56.44 points for the experimental class, and 56.34 for the control class, the average score of the two classes is only 0.1 points. It shows that the English proficiency of the two classes is similar at the beginning of the experiment, which is a requirement for the success of the experiment.

After one semester's study, the average scores of the experimental class and the control class are 69.13 and 60.89 respectively, that is, the average scores of the students in the experimental class has increased 8.24. While the average scores of the pre-test and post-test scores of the control class are 56.34 and 60.89 respectively. That is, after one semester's study of Blue Ink Cloud English learning, the average score of students increased by 4.55 points. The growth value of the experimental class is higher than that of the control class. By comparing the data, we find that information teaching can improve students' professional English ability, which proves the consistency of Blue ink cloud class teaching and college English teaching in terms of objectives.

\section{Changes in Student Learning Habits and Learning Styles}

The teaching mode based on Blue Ink Cloud Class can change students' learning habits and ways. Pre-study before class, discussion in class, and summary after class can fully stimulate students' enthusiasm for learning and improve learning efficiency. We should constantly guide students to use relevant platforms to choose their favorite courses. In the process of learning, we should participate in classroom discussions and take good notes, so as to improve students' learning ability and ability to obtain information.

\section{CONCLUSION}

Practice has proved that the use of foreign language information resources under the guidance of teachers plays a 
great role in pre-class, after-class and in-class teaching. The practical teaching based on Blue Ink Cloud Class is one aspect of the foreign language optimization strategy. The network of corrections and MOCC can also play an active role as a useful supplement to teaching practice.

Practical experience has proved that colleges and universities should not only invest a lot of hardware measures, but also guide foreign language teachers to design the use of information resources reasonably. It guides students to use the resources scientifically so that foreign language information resources can become beneficial assistants for foreign language autonomous learning.

\section{ACKNOWLEDGMENT}

The paper is one of research findings from the project "Research on the application of Cloud Class in College English listening and speaking" which is "the 13th Five year" social science project in the Department of Education in Jilin Province. The project number is ZD18103.

\section{REFERENCES}

[1] Alemi, M., Sarab, M. R. A., \& Lari, Z. (2012). Successful learning of academic word list via MALL: Mobile assisted language learning. International Education Studies, 5(6), 99-109.

[2] Allen, J. (Ed.). (2014). The media and the digital learning revolution. (pp. 82-84). Washington, DC: The Center for Education Reform.

[3] Bachore, M. M. (2015). Language Learning through Mobile Technologies: An Opportunity for Language Learners and Teachers. Journal of Education \& Practice, 6, 50-83.

[4] Benson P. (2006). Autonomy in language teaching and learning. Language Teaching, 40(01),21-40.

[5] Borup, J., Graham, C. R., \& Davies, R. S. (2013). The nature of adolescent learner interaction in a virtual high school setting. Journal of Computer Assisted Learning, 29(2), 153-167. 